\title{
Development and Use of Sintered Metal Filters with Fluidized Bed and Spray Calcination of Simulated High-Level Waste
}

by

W. J. Bjorklund

July 1976

Prepared for the Energy Research and Development Administration under Contract E(45-1):1830 
This report was prepared as an account of work sponsored by the United States Government. Neither the United States nor the Energy Research and Development Administration, nor any of their employees, nor any of their contractors, subcontractors, or their employees, makes any warranty, express or implied, or assumes any legal liability or responsibility for the accuracy, completeness or usefulness of any imformation, apparatus, product or process disclosed, or represents that its use would not infringe privately owned rights.

PACIFIC NORTHWEST LABORATORY

operated by

BATTELLE

for the

ENERGY RESEARCH AND DEVELOPMENT ADMINISTRATION

Under Contract E(45-1)-1830

\author{
Printed in the United States of America \\ Available from \\ National Technical Information Service \\ U.S. Department of Commerce \\ 5285 Port Royal Road \\ Springfield, Virginia 22151
}

Price: Prunted Copy \$5.00; Microfiche \$2.25 
BNWL-2074

UC -70

\section{7}

DEVELOPMENT AND USE OF SINTERED METAL FILTERS WITH FLUIDIZED BED AND SPRAY CALCINATION OF SIMULATED HIGH-LEVEL WASTE

by

W. J. Bjorklund

Ju1y 1976

Battelle

Pacific Northwest Laboratories

Richland, Washington 99352 


\section{ABSTRACT}

Sintered metal filters have been used for off-gas particulate ramoval on a pilot-scale fluidized bed calciner and spray calciner. The units calcined simulated commercial HLW at rates equivalent to 1 to $3 \mathrm{MTU} /$ day fuel reprocessed. Filters were cleaned by a periodic pulse of air in a reverse direction through the filters. Filter systems design and recommended operating parameters are described. 


\section{CONTENTS}

ABSTRACT. . .

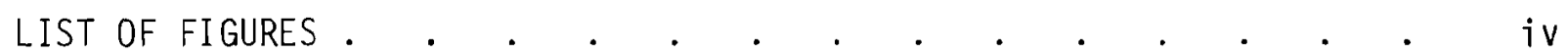

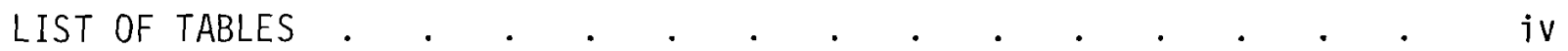

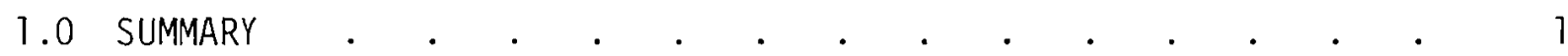

2.0 INTRODUCTION

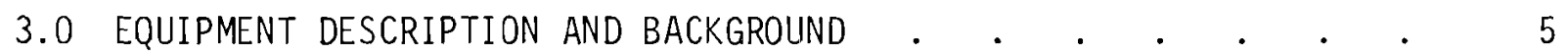

3.1 Filter Types . . . . . . . . . . . . . . . . . 5

3.2 Venturi Design . . . . . . . . . . . . . . . 5

3.3 Blowback Nozzle . . . . . . . . . . . . . . . . 8

3.4 Simulated HLW Calcine . . . . . . . . . . . . 13

4.0 TESTING RESULTS . . . . . . . . . . . . . . . . . . . 17

4.1 Fluidized Bed . . . . . . . . . . . . . . . . 17

4.2 Improved Filter Vessel . . . . . . . . . . . . 22

4.3 Spray Calciner . . . . . . . . . . . . . . . . . 26

5.0 CONCLUSIONS AND RECOMMENDATIONS . . . . . . . . . . . . . 31

6.0 REFERENCES . . . . . . . . . . . . . . . . . . . 33 


\section{LIST OF FIGURES}

1 Typical Filter and Blowback System . . . . . . . . 4

2 Various Filter Types . . . . . . . . . . . . 47

3 Venturi Designs Tested in Fluidized Bed . . . . . . .9

4 Venturi Design Used in Spray Calciner . . . . . . . 10

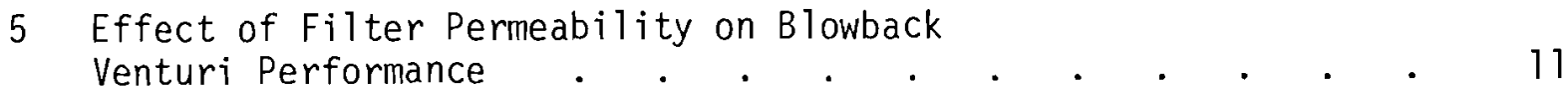

6 Fluidized Bed Filtering System . . . . . . . . . . 18

7 Permeability Data for Fluidized Bed Calciner . . . . . 22

8 New Filter Vessel . . . . . . . . . . . . . . . 24

9 Filter Vessel Layout and Venturi Arrangement . . . . . 25

10 Spray Calciner Filters and Blowback Apparatus . . . . . 27

11 Spray Calciner Filter Differential Pressure . . . . . 28

12 Off-Gas Filters Following 500-Hr Run . . . . . . . 29

13 Spray Calciner Permeability Data . . . . . . . . 29

\section{LIST OF TABLES}

1 Properties of Porous Stainless Steel . . . . . . . 6

2 Flow Capacity--Air. . . . . . . . . . . . . 6

3 Venturi Dimensions for Entrainment Tests . . . . . . 11

4 Compositions of Representative High-Level Radioactive 14

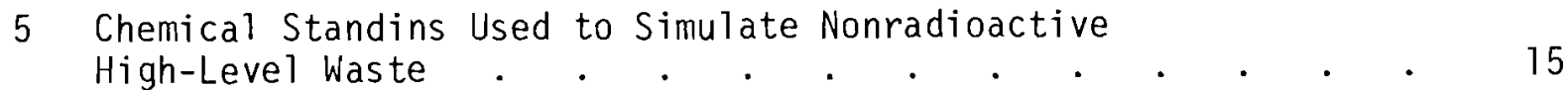

6 Characteristics of Calcine . . . . . . . . . . 17

7 Size Distribution of Material Elutriated to Filters 19

8 Size Distribution of Fluidized Bed Calcine Fines with Intentional Attrition . . . . . . . . . . 19

9 Particles Passing Through New 65-Micron Filter . . . . . 20

10 Fluidized Bed Calciner Off-Gas Sampling . . . . . . 20

11 Fluidized Bed Calciner Off-Gas Composition . . . . . . 21

12 Properties of Spray Calcine . . . . . . . . . . 26

13 Operating Ranges . . . . . . . . . . . . . . 26 


\subsection{SUMMARY}

Sintered metal filters were used to filter the particulate entrained in the off-gas from both a spray calciner and fluidized bed calciner. Blowback of air directed into venturi tubes in the end of each filter was used to periodically knock the accumulated cake of powder from the filters. Significantly reduced blowback frequency--hours rather than minutes--was found to be effective, and better at maintaining a suitable pressure drop, normally 5 to 15 in. of $\mathrm{H}_{2} \mathrm{O}$. Sophisticated blowback nozzle and venturi designs were not necessary although certain basic operating parameters were required, including the use of venturis, high-pressure (>60 psig) blowback air and a timing system for providing short pulses of air.

The use of in-bed combustion heating in the fluidized bed calciner showed no effect on filter performance.

Filter designs were generally aimed at keeping the face velocity* as low as possible $(<3 \mathrm{ft} / \mathrm{min})$ and allowing a cake of powder to accumulate on the filter until pressure drop across the filter interfered with normal system pressure. At this point blowback with air was used to clean the filter bank.

The filters were very efficient. Particulate losses less than 0.025 wt\% were noted with the fluidized bed. DFs, based on total solids loading in the

off-gas, ranged from $10^{3}$ to $10^{5}$. No problems are foreseen in using a properly designed filter system for a remotely operated hot cell.

\footnotetext{
* Face Velocity: velocity of off-gas passing through the filters based on actual conditions. $\frac{\mathrm{ft}^{3} / \mathrm{min} \text { gas } \mathrm{flow}}{\mathrm{ft}^{2} \text { filter area }}=\mathrm{ft} / \mathrm{min}$
} 


\subsection{INTRODUCTION}

Sintered metal filters have been used for the primary filtration of the off-gas from spray and fluidized bed calciners. This work has been aimed specifically at gaining experience with these filters which would be directly applicable to commercial design of calcination units. Simulated high-level waste representative of that from a commercial fuel reprocessing plant has been calcined.

General operation of a particulate filtering system using porous sintered metal, whether for a fluidized bed or spray calciner or other similar process, is basically the same. A gas stream containing entrained solids impinges on the filter, which becomes increasingly coated with the material. The coating eventually becomes thick enough or is so impervious that the pressure drop across the cake and filter becomes higher than desired operations permit. A blowback pulse of gas (air or steam) directed into venturi tubes located in the top of each filter sends a reverse flow of gas through the filters. This pulse knocks the powder coating off, reducing the pressure drop. It has been postulated that the mechanism for removing the coating is the shock wave created by the air introduced from a nozzle above each filter. Depending on the operating conditions, nature of the material being handled, etc., blowback can continue on a cycle varying from a minute to several hours. A typical blowback system is shown in Figure 1.

Many investigators have reported similar operations. A summary report on blowback experience with small sized calcining units is available. (1) Battelle has published data on the performance of sintered metal filters used in spray calciner hot cell testing at Battelle. $(2,3)$

During calcining of simulated nuclear wastes, the coating on the filters is typically about $1 / 16$ to $1 / 8 \mathrm{in}$. thick when operating with total pressure drops across the filters of between 5 and 30 in. of water. Gas flows of 


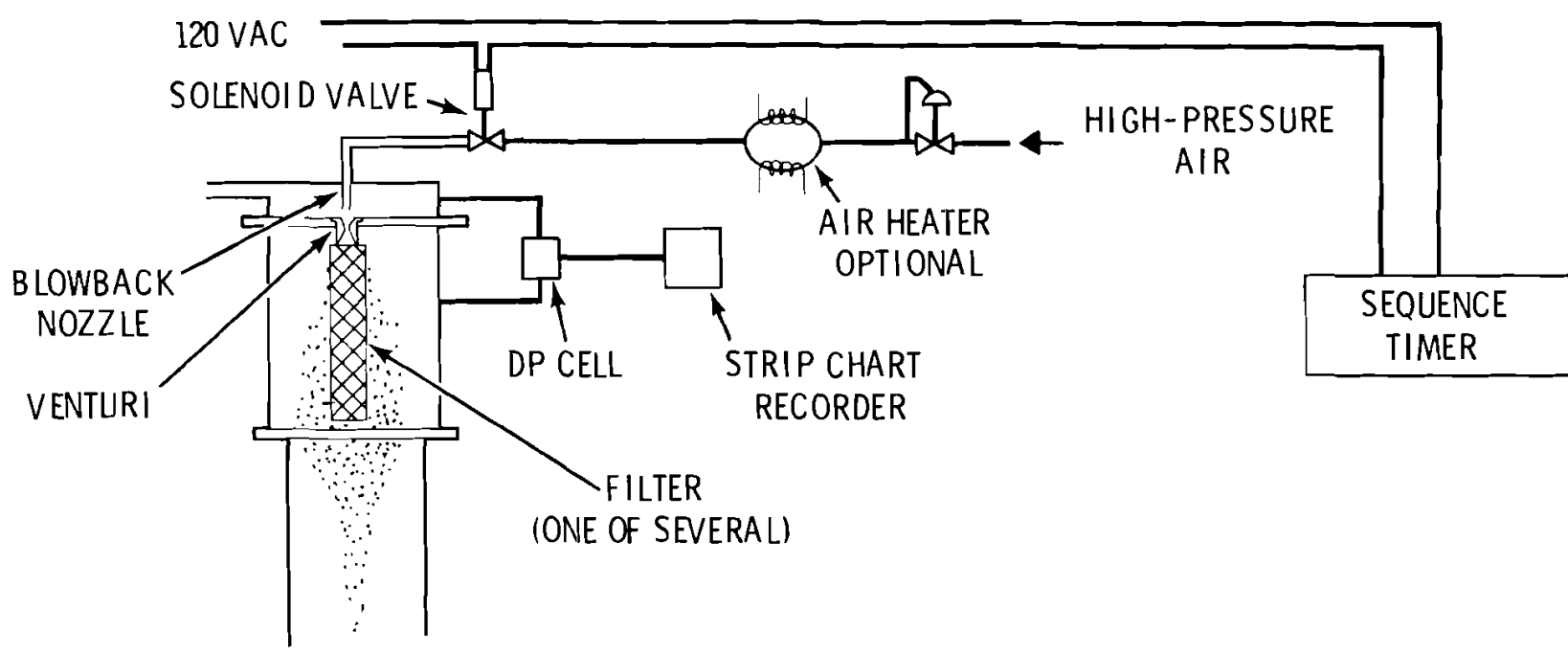

FIGURE 1. Typical Filter and Blowback System

2 to $5 \mathrm{acfm} / \mathrm{ft}^{2}$ of filter area are typical. Air either heated or unheated has been used for blowback. Earlier work with spray calciners has shown superheated steam to be as effective as air. (4) The steam is subsequently condensed, hence reducing the off-gas to be handled downstream; however, the amount of gas required for blowback is generally insignificant when compared to the total volume processed. Pressure surges in the equipment have been noted to be higher during air blowback than with steam. 


\subsection{EQUIPMENT DESCRIPTION AND BACKGROUND}

\section{1 FILTER TYPES}

Most recent testing with the fluidized bed and spray calciner has been with off-the-shelf commercial manufactured filters.* Various lengths from 18 to $36 \mathrm{in.}$ and diameters from 2 to $2-3 / 4 \mathrm{in}$. have been used. Typically coarse-grade filters (Grade D) were used. See Tables 1 and $2^{(6)}$ for filter properties and capacities. Grade D filters are rated $98 \%$ efficient at removing $8-\mu$ sized particles and $100 \%$ efficient on $20-\mu$ size. A reinforcing grid has been added for strength. Figure 2 is a photo of some filters tested.

\section{TABLE 1. Properties of Porous Stainless Stee1}

\begin{tabular}{|c|c|c|c|c|c|}
\hline & & & de Designat & & \\
\hline & $\begin{array}{c}0 \\
\text { Coarse } \\
\end{array}$ & $\begin{array}{c}E \\
\text { Medium }\end{array}$ & $\begin{array}{c}F \\
\text { Fine } \\
\end{array}$ & $\begin{array}{c}G \\
\text { Extra-Fine } \\
\end{array}$ & $\begin{array}{c}11 \\
\text { Superfine }\end{array}$ \\
\hline Particle diameter of powder, im & $150-300$ & $75-150$ & $75-150$ & $35-75$ & $20-60$ \\
\hline Mean pore opening, ill & 65 & 35 & 20 & 10 & 5 \\
\hline Minimum tensile strength, $1 b /$ in. $^{2}$ & 9000 & 75,000 & 15,000 & 15,000 & 15,000 \\
\hline Minimum thickness, in. & $1 / 16$ & $1 / 32$ & $1 / 32$ & $1 / 32$ & $1 / 32$ \\
\hline Approximate modulus of elasticity & $1.0 \times 10^{6}$ & $1.5 \times 10^{6}$ & $2.5 \times 10^{6}$ & $2.7 \times 10^{6}$ & $3.0 \times 10^{6}$ \\
\hline Elongation (min) & 5 & 5 & 5 & 4 & 2 \\
\hline
\end{tabular}

Earlier testing of filters on spray calcination equipment was done with porous alumina, $304 \mathrm{~L}$ stainless stee $1,316 \mathrm{~L}$ stainless steel porous metal, and $304 \mathrm{~L}$ wire wound filters. (7) Wire wound and $316 \mathrm{~L}$ porous metal filters appeared to perform as well as $304 \mathrm{~L}$ filters. The porous alumina (ceramic) filters had $3 / 8 \mathrm{in}$. thick walls, were hard to clean by blowback, and were replaced by sintered metal.

* No attempts have been made to compare vendors or seek out all suppliers. Likewise there is no reason to believe that one brand differs significantly from another. 


\section{TABLE 2. Flow Capacity--Air}

\begin{tabular}{|c|c|c|c|c|c|}
\hline $\begin{array}{l}\text { Pressure Drop, } \\
\text { 1b/in. }{ }^{2} \\
\end{array}$ & $\mathrm{Flo}$ & $\begin{array}{r}\text { acity } \\
\mathrm{Cl} \\
\end{array}$ & $\begin{array}{l}/ 8-i n \\
i r / M i\end{array}$ & $c k F$ & \\
\hline & $\bar{D}$ & $E$ & $F$ & $G$ & $\bar{H}$ \\
\hline 0.01 & 13 & - & - & - & - \\
\hline 0.05 & 60 & 18 & 5 & 3 & 1.8 \\
\hline 0.1 & 115 & 35 & 9 & 5 & 3.5 \\
\hline 0.2 & 175 & 65 & 18 & 10 & 7 \\
\hline 0.5 & 320 & 140 & 44 & 24 & 17 \\
\hline 1.0 & 475 & 220 & 82 & 41 & 28 \\
\hline 2.0 & 685 & 340 & 160 & 66 & 46 \\
\hline 5.0 & 1045 & 580 & 320 & 140 & 90 \\
\hline 10.0 & - & 900 & 460 & 250 & 160 \\
\hline
\end{tabular}

a. For $1 / 16-i n$. thick filters, multiply results given by two.

\subsection{VENTURI DESIGN}

Venturi tubes are used in the throats of the filters to effectively remove powder. Their use also entrains off-gas, thus conserving the total gas input to the system. See Section 3.3. Schneider observed in spray calciner work that no dust was removed without venturis and that an orifice in place of a venturi was considerably less effective. (2) The specific design of the venturi, however, does not appear critical. Schneider also observed that increasing the cone angle up to $60^{\circ}$ and $30^{\circ}$ for the upstream and downstream angles (viewed from the nozzle) had little effect.

Kaser's work ${ }^{(8)}$ on venturi design for a spray calciner indicated that at higher permeabilities ( 5 to $10 \mathrm{cfm} / \mathrm{in} .-\mathrm{H}_{2} \mathrm{D} \mathrm{ft}^{2}$ ) larger throated venturis 


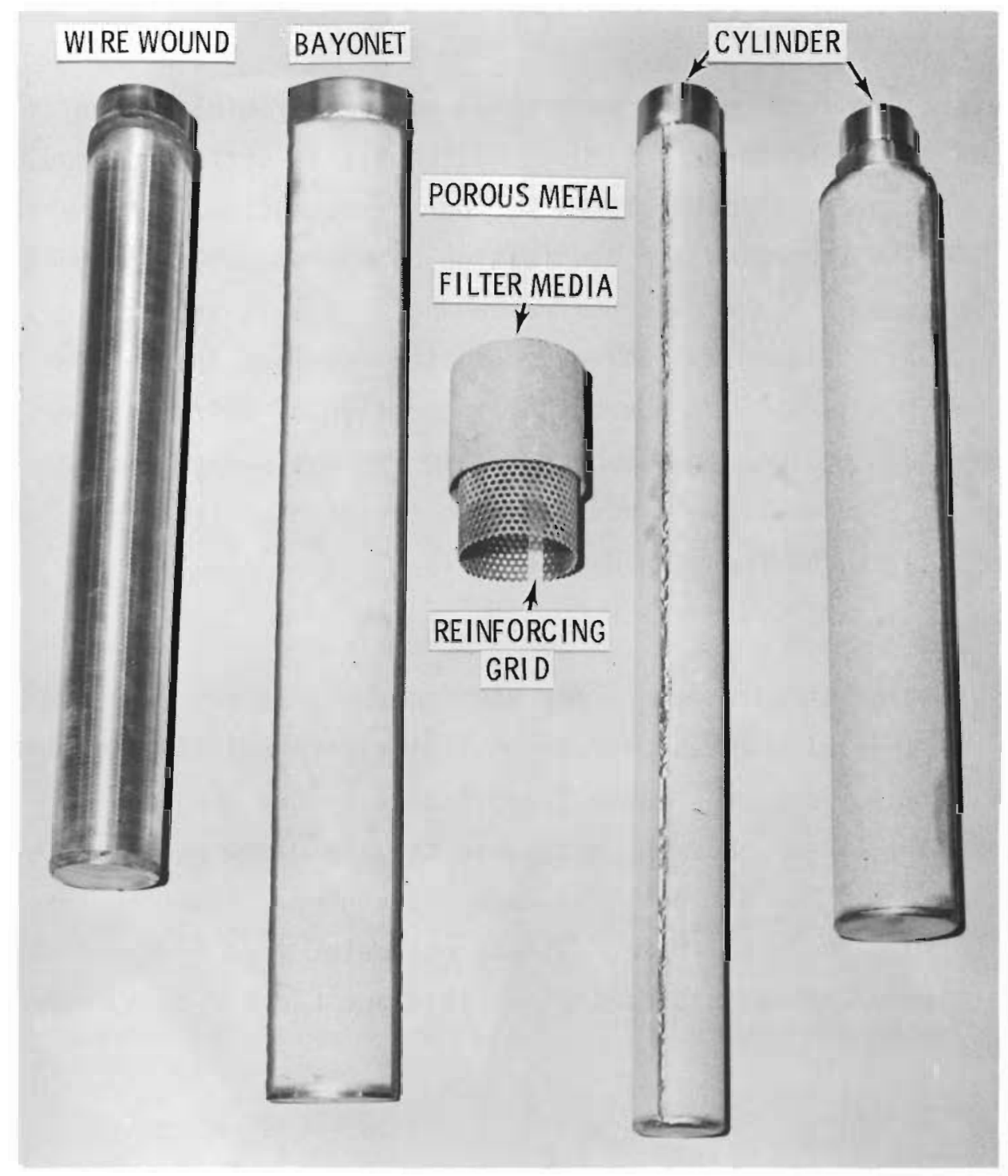

FIGURE 2. Various Filter Types

( 1.5 to $1.75 \mathrm{in}$. diam) performed better, but at lower permeabilities ( 2 to 3 $\mathrm{cfm} / \mathrm{in}$. $-\mathrm{H}_{2} \mathrm{O} \mathrm{ft}^{2}$ ) throat sizes of 0.75 to 1 in. were better.* An analogous situation, the treatment of jet ejectors, shows the throat diameter decreasing with increasing discharge pressure. ${ }^{(8)}$ Narrow throated ( $<1$ in.) venturis gave superior performance in a spray calciner if the filter cake was wet or sticky. ${ }^{(7)}$

$\bar{*}$ Permeability: $\frac{\text { acfm of off-gas }}{\text { filter } \Delta P \cdot \mathrm{ft}^{2} \text { filter area }}$ 
Several venturi designs were tried with the fluidized bed filters and are shown in Figure 3a-d. Of those tested little difference could be seen from visual observation of blowback. During operation, pen chart recordings of the impulse from blowback (indication of overpressure*) showed that venturis designed with a greater entrance angle to exit angle, i.e., $60^{\circ}$ to $30^{\circ}$ and $30^{\circ}$ to $15^{\circ}$ (Figure $3 \mathrm{a}, 3 \mathrm{~b}$ ) gave greater impulses than either $50^{\circ}$ to $40^{\circ}$ or $30^{\circ}$ to $45^{\circ}$. This was not obvious by inspection of filters after the run, however. Venturi design and blowback nozzle for the spray calciner filters are as shown in Figure 4. This design works satisfactorily also. Additional venturi designs can be found in Reference 1.

\section{Entrainment}

The amount of entrainment for various venturis was measured by Kaser and Moore. (7) They also included data on filter permeability and nozzle to venturi throat distance. Table 3 and Figure 5 show these data. These venturis are all larger than those used in the fluidized bed or recent spray calciner tests, and the permeability range is higher. Also the throat to nozzle length ( 3 to 6 in.) is larger. It was estimated from Figure 5 that entrainment ratios for venturis used in the fluidized bed and spray calciner were about 0.5 .

\subsection{BLOWBACK NOZZLE}

Blowback gas, whether air or steam, is directed into the venturi through some type of nozzle to set up an overpressure in the filter. Dust removal increases with overpressure induced by blowback gas. (9) Studies by Schneider ${ }^{(2)}$ on filtering spray calciner off-gas through 2-in. diam $\times 24-i n$. long filters indicate:

1. Overpressure attains a steady state $0.2 \mathrm{sec}$ after the blowback valve is opened.

2. Overpressure is evenly distributed over the filter face except near the venturi end, where it is less.

* Overpressure: difference in pressure between the upstream and downstream filter faces during blowback. 


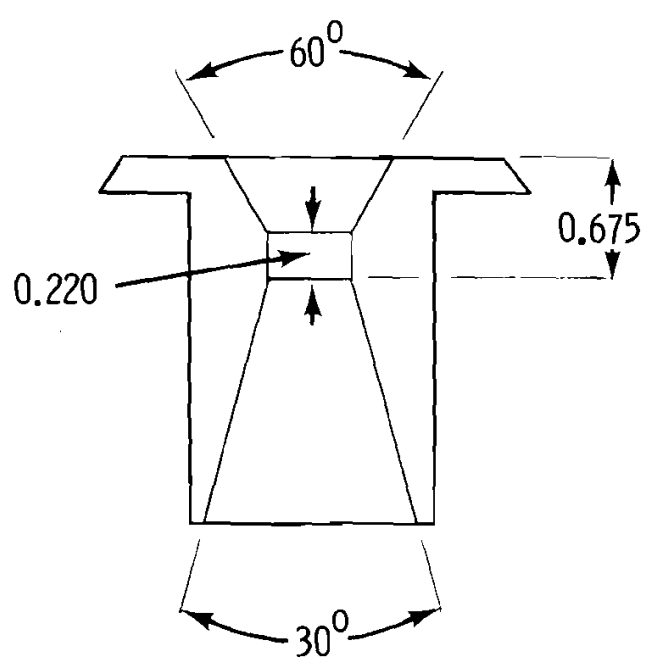

a.

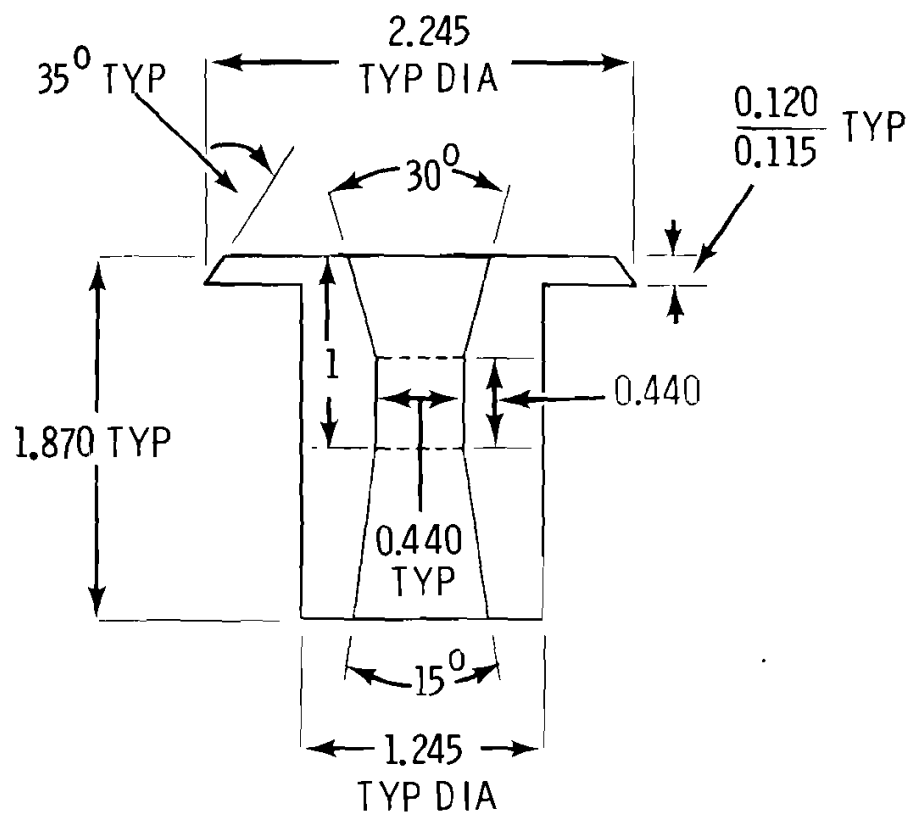

b.

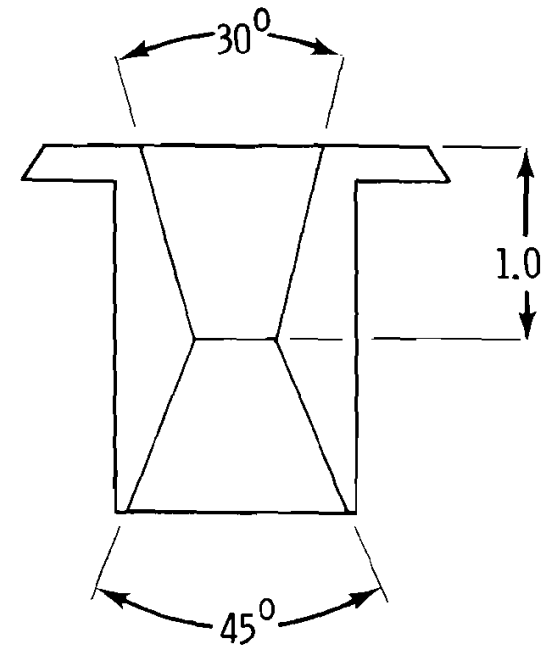

c.

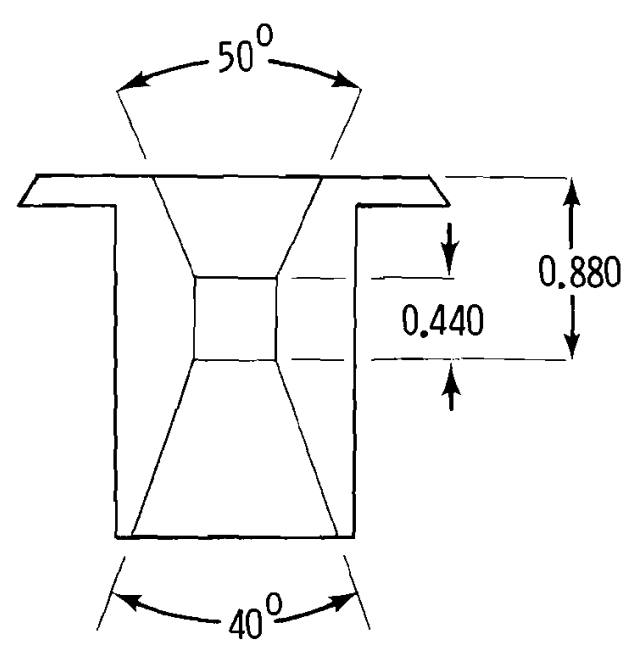

d.

FIGURE 3. Venturi Designs Tested in Fluidized Bed 


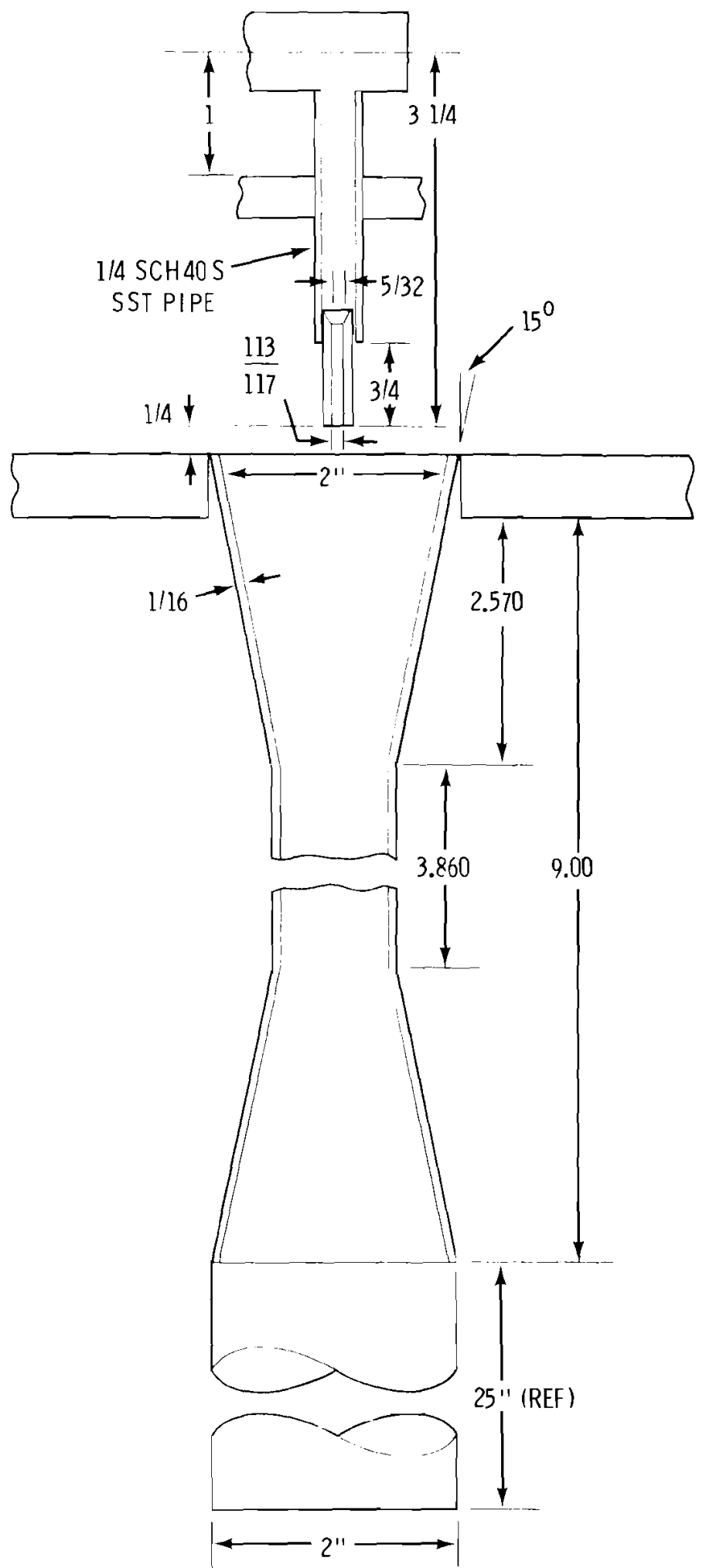

FIGURE 4. Venturi Design Used in Spray Calciner 
TABLE 3. Venturi Dimensions for Entrainment Tests

\section{Venturi Designation}

Entrance cone angle, degrees

Side length of entrance cone, in.

Throat diameter, in.

Throat length, in.

Diffuser, in.

Side length of diffuser, in.

optimum distance from blowback nozzle to throat, in. (a)

\begin{tabular}{|c|c|c|c|c|}
\hline A & $B$ & $\mathrm{C}$ & D & $E$ \\
\hline 60 & 30 & 60 & 60 & 30 \\
\hline 2.65 & 3.85 & 1.85 & 2.45 & 3.38 \\
\hline 0.75 & 1.5 & 1.75 & 1.0 & 0.75 \\
\hline 1.0 & 0 & 1.0 & 1.0 & 1.0 \\
\hline 30 & 60 & 15 & 30 & 14 \\
\hline 5.0 & 1.75 & 6.1 & 4.6 & 10.25 \\
\hline $3-4$ & 6 & 6 & 4 & 4 \\
\hline
\end{tabular}

a. Largest entrainment ratio.

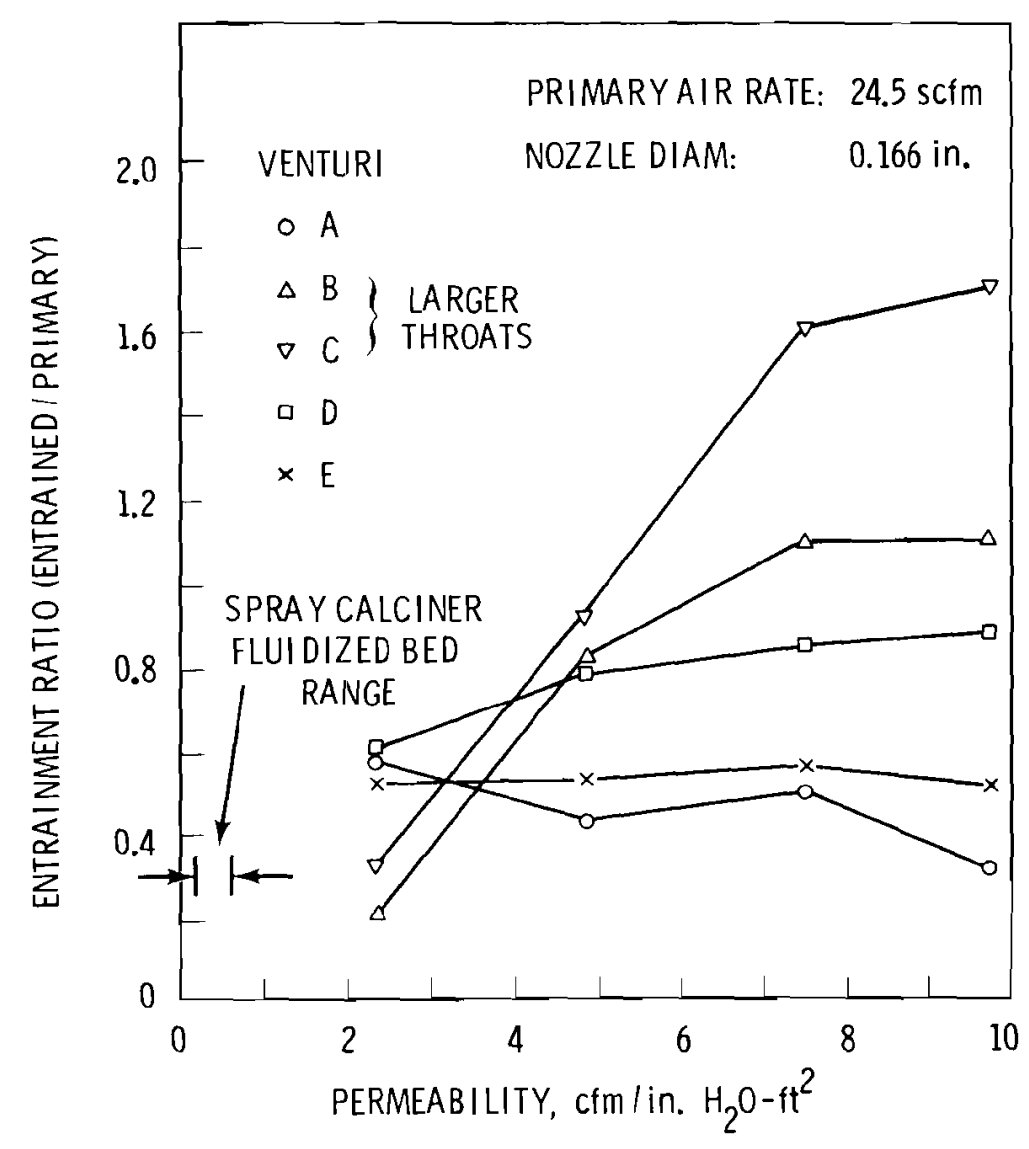

FIGURE 5. Effect of Filter Permeability on Blowback Venturi Performance 
3. Optimum spacing between the venturi throat and nozzle are in the range of 2 to 6 in.

4. Increasing the same flowrate to sonic velocity increases overpressure.

5. Overpressure increases with blowback gas flowrate.

6. Increasing filter plus cake permeability reduces overpressure attainable. Spray calciner work by Kaser and Moore ${ }^{(7)}$ indicated the optimum ratio of blowback nozzle diameter to venturi throat diameter was 0.22 and suggested further improvement by using convergent-divergent nozzles to produce supersonic exit velocities. The nozzle has little effect on overpressure if the flowrate is constant and the velocity sonic. (8)

Blowback tubes on the spray calciner moved from $2 \mathrm{in}$. above to $1 / 2 \mathrm{in}$. above the support plate showed no difference in dust removal. (10)

Fluidized bed blowback tubes are located $23 / 8$ in. above the venturi. Changes in height have not been investigated.

\section{Pulse Duration}

The amount of air pulsed into the filters is not clearly defined. Argonne National Laboratory (ANL) data with 80 to 100 psig blowback air through $1 / 32$ to 1/16-in. nozzles showed no difference in blowback performance when the pulse duration varied from 0.2 to $1.4 \mathrm{sec} .{ }^{(1)}$ Spray calciner work at BNWL reported by Spaeth indicated that pulse lengths less than $0.5 \mathrm{sec}$ allowed the filters to plug. (5) Work with the fluidized bed has been done with pulse time of 0.18 to $0.75 \mathrm{sec}$ with no noticeable difference. Recent spray calciner work has had satisfactory blowback with a $0.25 \mathrm{sec}$ pulse. It appears that pulse duration less than $1 \mathrm{sec}$ is sufficient. The volume of air in a pulse has not been measured at Battelle. ANL reported a 1 -sec pulse through a $1 / 8$ in. solenoid and $1 / 16$ in. nozzle passed $0.1 \mathrm{ft}^{3}$. Sonic velocity is reached at a gas rate of $0.1 \mathrm{ft}^{3} / \mathrm{sec}$ through a $1 / 8 \mathrm{in}$. tube. This has been the assumed rate for calculations in this report. At pulse lengths less than $1 \mathrm{sec}$, a directly proportional reduction in air volume has been assumed. 
To minimize plugging the optimum ratio of blowback gas rate to filtering gas rate was given by a filter manufacturer as $0.5 .^{(4)}$ The volume of pulse to internal filter volume of 0.5 to 8.0 was recommended by ANL work. (1)

The fluidized bed has 36 and 18-in. length filters with internal volumes of 0.12 and $0.06 \mathrm{ft}^{3}$, respectively. Assuming that a $0.25-\mathrm{sec}$ pulse would release $0.025 \mathrm{ft}^{3}$ of gas plus an additional $0.012 \mathrm{ft}^{3}$ of entrained air, the ratio of pulse volume to filter volume would be 0.31 and 0.62 for 36 and $18-i$. filters, on the low end of the ANL data. The blowback gas rate to filtering gas rate ratio for a single $36-i n$. filter would be 2.96 . This is higher than the recommended rate; however, this data is questionable because of the uncertainty in the blowback gas flow through the filter. Experience at Battelle has not shown plugging to be a problem, and ANL work with rate ratios of 1.3 to 10 was all considered satisfactory. (1)

\subsection{SIMULATED HLW CALCINE}

The sintered metal filters have been used to filter the off-gas from the calcination of a range of commercial waste types. These representative wastes processed in either the fluidized bed or spray calciner are listed in Table 4. For reasons as listed in Table 5 , some chemical substitutions are made for the pilot plant tests. 
TABLE 4. Compositions of Representative High-Level Radioactive Wastes after Conversion to Calcine

\begin{tabular}{|c|c|c|c|c|c|c|c|c|c|}
\hline & \multicolumn{9}{|c|}{ Kilograms Oxide /MTU } \\
\hline & & $\overline{\mathrm{P}} \overline{\mathrm{W}}-4 \mathrm{~b}$ & $\mathrm{PW}-4 \mathrm{C}$ & $\mathrm{PW}-6$ & PW $-\overline{7}$ & $\overline{\mathrm{PW}}-7 \overline{\mathrm{a}}$ & $\overline{P W}-7 \mathrm{~b}$ & $\overline{P W}-8$ & PW-Ba \\
\hline Inerts & $\mathrm{Na}_{2} \mathrm{O}$ & - & 1.126 & 23.459 & 0.117 & 6.872 & 6.872 & - & 14.057 \\
\hline \multirow{30}{*}{$\begin{array}{l}\text { Fission } \\
\text { Products } \\
\text { (Same } \\
\text { for all } \\
\text { wastes) }\end{array}$} & $\mathrm{Fe}_{2} \mathrm{O}_{3}$ & 1.511 & 1.511 & 15.112 & 3.022 & 3.022 & 17.711 & 39.895 & 27.225 \\
\hline & $\mathrm{Cr}_{2} \mathrm{O}_{3}$ & 0.345 & 0.345 & 1.295 & 0.345 & 0.345 & 0.345 & 1.151 & 1.151 \\
\hline & $\mathrm{NiO}$ & 0.141 & 0.141 & 0.566 & 0.141 & 0.141 & 0.141 & 0.566 & .566 \\
\hline & $\mathrm{P}_{2} \mathrm{O}_{5}$ & 0.672 & 0.672 & 0.672 & 2.686 & 6.339 & 6.339 & 1.340 & 1.340 \\
\hline & ${ }^{A} 2_{2}{ }_{3}$ & - & $83.937^{(a)}$ & - & - & - & - & - & - \\
\hline & $\mathrm{Gd}_{2} \mathrm{O}_{3}$ & - & - & - & 10.360 & 10.360 & 10.360 & - & - \\
\hline & Subtotal & 2.669 & 87.732 & 41.104 & 16.671 & 27.079 & 41.768 & 42.952 & 44.339 \\
\hline & $\mathrm{Rb}_{2} \mathrm{O}$ & & & & 0.354 & & & & \\
\hline & sro & & & & 1.059 & & & & \\
\hline & $\mathrm{Y}_{2} \mathrm{O}_{3}$ & & & & 0.598 & & & & \\
\hline & $\mathrm{ZrO}_{2}$ & & & & 4.944 & & & & \\
\hline & $\mathrm{MoO}_{3}$ & & & & 5.176 & & & & \\
\hline & $\mathrm{Tc}_{2} \mathrm{O}_{7}$ & & & & 1.291 & & & & \\
\hline & $\mathrm{RuO}_{2}$ & & & & 2.972 & & & & \\
\hline & $\mathrm{Rh}_{2} \mathrm{O}_{3}$ & & & & 0.480 & & & & \\
\hline & $\operatorname{Pdo}$ & & & & 1.483 & & & & \\
\hline & $\mathrm{Ag}_{2} \mathrm{O}$ & & & & 0.088 & & & & \\
\hline & $\mathrm{CdO}$ & & & & 0.097 & & & & \\
\hline & $\mathrm{TeO}_{2}$ & & & & 0.725 & & & & \\
\hline & $\mathrm{Cs}_{2} \mathrm{O}$ & & & & 2.880 & & & & \\
\hline & $\mathrm{BaO}$ & & & & 1.567 & & & & \\
\hline & $\mathrm{La}_{2} \mathrm{O}_{3}$ & & & & 1.480 & & & & \\
\hline & $\mathrm{CeO}_{2}$ & & & & 3.323 & & & & \\
\hline & $\operatorname{Pr}_{6}{ }^{0} 11$ & & & & 1.482 & & & & \\
\hline & $\mathrm{Nd}_{2} \mathrm{O}_{3}$ & & & & 4.522 & & & & \\
\hline & $\mathrm{Pm}_{2} \mathrm{O}_{3}$ & & & & 0.123 & & & & \\
\hline & $\mathrm{Sm}_{2} \mathrm{O}_{3}$ & & & & 0.924 & & & & \\
\hline & $\mathrm{Eu}_{2} \mathrm{O}_{3}$ & & & & 0.200 & & & & \\
\hline & $\mathrm{Gd}_{2} \mathrm{O}_{3}$ & & & & 0.137 & & & & \\
\hline & $\begin{array}{l}\text { Subtotal } \\
\mathrm{U}_{3} \mathrm{O}_{8}\end{array}$ & 1.169 & 1.169 & 5.738 & $\begin{array}{l}35.905 \\
11.689\end{array}$ & 11.689 & 11.689 & 5.526 & 11.689 \\
\hline \multirow{5}{*}{ Actinides } & $\mathrm{NpO}_{2}$ & 0.865 & 0.865 & 0.865 & 0.865 & 0.865 & 0.865 & 0.865 & .855 \\
\hline & $\mathrm{PuO}_{2}$ & 0.010 & 0.010 & 0.051 & 0.103 & 0.703 & 0.103 & 0.051 & .174 \\
\hline & $\mathrm{Am}_{2} \mathrm{O}_{3}$ & 0.181 & 0.181 & 0.181 & 0.181 & 0.781 & 0.181 & 0.181 & .181 \\
\hline & $\begin{array}{l}\mathrm{Cm}_{2} \mathrm{O}_{3} \\
\text { Subtotal }\end{array}$ & $\begin{array}{l}0.040 \\
2.265\end{array}$ & $\begin{array}{l}0.040 \\
2.265\end{array}$ & $\begin{array}{l}0.040 \\
6.875\end{array}$ & $\begin{array}{r}0.040 \\
12.878\end{array}$ & $\begin{array}{r}0.040 \\
12.878\end{array}$ & $\begin{array}{r}0.040 \\
12.978\end{array}$ & $\begin{array}{l}0.040 \\
6.663\end{array}$ & $\begin{array}{r}.040 \\
12.949\end{array}$ \\
\hline & & 40.8 & 125.9 & 83.9 & 65.5 & 75.9 & 90.5 & 85.5 & 93.2 \\
\hline
\end{tabular}

a. Seed particles used as starting bed in fluidized bed calciner. 
TABLE 5. Chemical Standins Used to Simulate Nonradioactive High-Level Waste(a)

\begin{tabular}{|c|c|c|}
\hline $\begin{array}{c}\text { Waste Constituent } \\
\text { to be } \\
\text { Substituted }\end{array}$ & $\begin{array}{l}\text { Reason for } \\
\text { Substitution } \\
\end{array}$ & $\begin{array}{c}\text { Substitute } \\
\text { Used (b) }\end{array}$ \\
\hline $\mathrm{Rb}$ & Expense & K \\
\hline$Y$ and $R E$ & $\begin{array}{l}\text { Expensive to simulate } \\
\text { fission product } \\
\text { spectrum }\end{array}$ & $\begin{array}{l}\text { Commercially available } \\
\text { rare earth mixtures }\end{array}$ \\
\hline Tc & $\begin{array}{l}\text { No nonradioactive } \\
\text { isotopes }\end{array}$ & Mo \\
\hline $\mathrm{Ru}$ & Expense & $\mathrm{Fe}$ \\
\hline $\mathrm{Rh}$ & Expense & Co \\
\hline $\mathrm{Pd}$ & Expense & $\mathrm{Ni}$ \\
\hline$C s(c)$ & Expense & K \\
\hline $\mathrm{U}, \mathrm{Np}, \mathrm{Pu}, \mathrm{Am}$ and $\mathrm{Cm}$ & $\begin{array}{l}\text { No nonradioactive } \\
\text { isotopes }\end{array}$ & Rare earths \\
\hline
\end{tabular}

a. Inexpensive nonradioactive isotopes are available for all of the fission products not shown.

b. Substitutes shown are those which have been used in the waste Fixation Program at PNL.

c. Substituted in engineering-scale tests only. 


\subsection{TESTING RESULTS}

\subsection{FLUIDIZED BED}

Work at PNL has been primarily oriented toward unconventional calcination techniques such as inert bed operation, attrition/elutriation, etc. This development work has produced operating conditions in which the product characteristics are in ranges wider than normally experienced when a fixed operating concept is used or conventional calcination is done. Typical characteristics of calcine are shown in Table 6 .

The amount of characteristics of fines that reach the sintered metal filters in the fluidized bed calciner can vary over a wide range, depending on how the calciner is operated. Unlike a spray calciner, which generates typically similar sized particles, fluidized bed calcination is a coating process that generates fines by abrasion of bed particles, by external attriting forces such as jet grinders, and by some spray drying. The amount and nature of these fines can be varied, depending on the needs of the operation.

TABLE 6. Characteristics of Calcine ${ }^{(a)}$

$\begin{array}{lll}\text { Size, mm } & \text { Bed } & 0.15-0.50 \\ & \text { Fines } & 0.04-0.15 \\ \text { Density, g/cc } & & 1.5-2.5 \\ \text { Nitrate, wt\% } & & 0.02-10 \\ \mathrm{H}_{2} \mathrm{O}, \text { wt\% } & 0.06-1.2\end{array}$

a. Characteristics of fluidized bed calcine will vary greatly, depending on operating temperature, type of feed, operating conditions, etc.

The initial configuration of the fluidized bed calciner process had the filters adjacent to the calcining vessel (Figure 6). Over $250 \mathrm{hr}$ of operation were completed with this arrangement. At this point modifications to the system were made to increase the filtering area (discussed in section 3 ). 


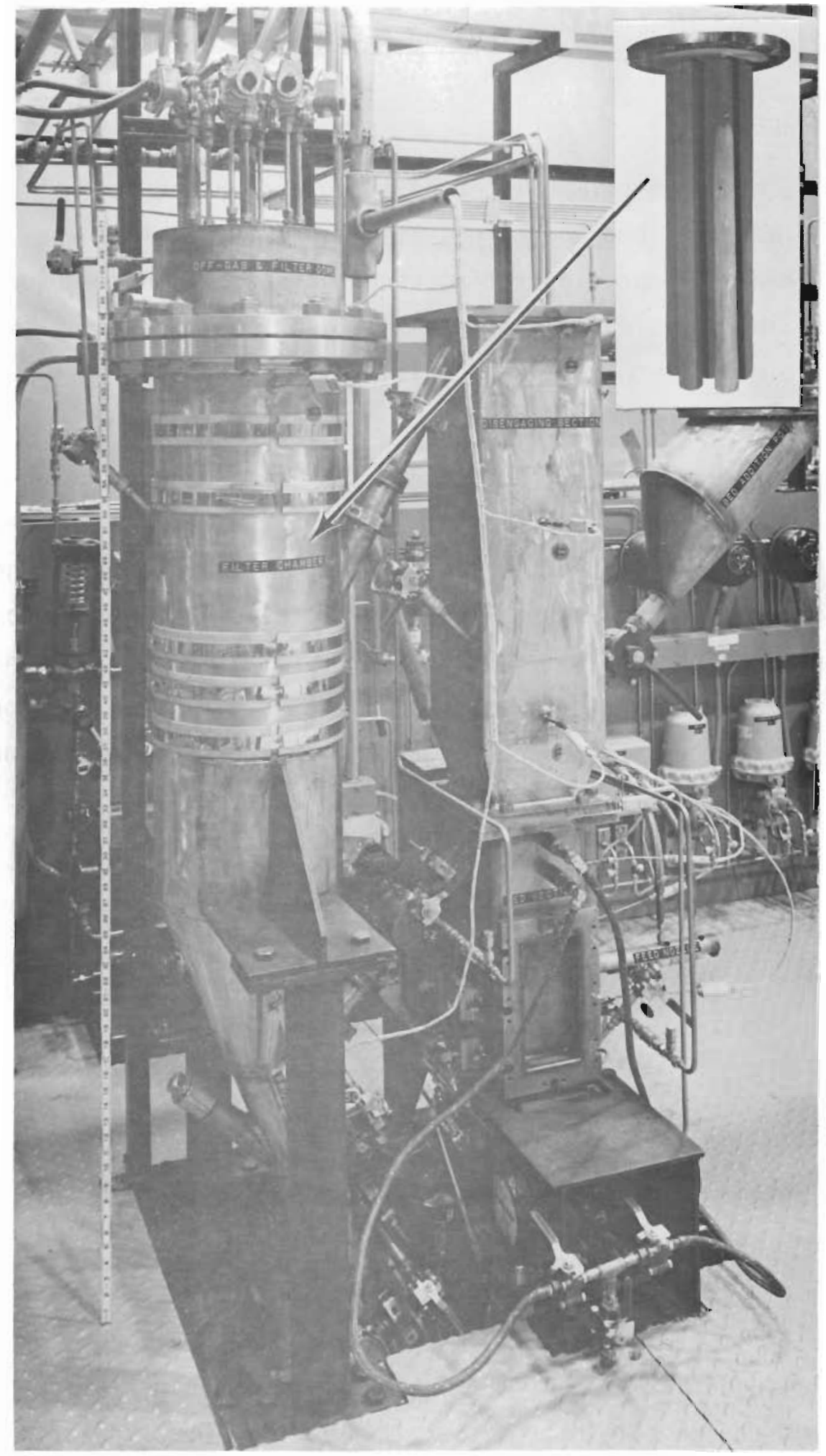

FIGURE 6. Fluidized Bed Filtering System 
Seven 36-in. x 2-3/4-in. filters were housed in a 12-in. diam Sch 10 s type $304 L$ SST pipe used as the filter vessel. Venturi tubes as shown in Figure $3 a$ were used with 3/8-in. diam $\times 0.12$ wall tubing as blowback nozzle. Each nozzle was $3 / 8 \mathrm{in}$. above the venturi.

During typical operation all material elutriated from the bed and carried to the filtering vessel was $<149 \mu$. A typical distribution is shown in Table 7 .

TABLE 7. Size Distribution of Material Elutriated to Filters in the Fluidized Bed

\begin{tabular}{cr} 
Size, $\mu$ & Wt\% \\
\hline 210 & 0.85 \\
149 & 0.70 \\
74 & 13.57 \\
37 & 59.06 \\
20 & 14.84 \\
10 & 10.22 \\
$<10$ & 0.76
\end{tabular}

With intentional attrition (by means of jet grinder or high air flow through a nozzle) the size distribution is changed as shown in Table 8. The significant increase is in the $-44 \mu$ ( 2325 mesh) range.

TABLE 8. Size Distribution of Fluidized Bed Calcine Fines with Intentional Attrition

\begin{tabular}{|c|c|c|}
\hline Size, & $\mu^{(a)}$ & wt $\%$ \\
\hline & +105 & 10.7 \\
\hline-105 & +88 & 8.4 \\
\hline-88 & +74 & 7.7 \\
\hline-74 & +53 & 9.6 \\
\hline-53 & +44 & 22.6 \\
\hline & -44 & 41.1 \\
\hline
\end{tabular}

a. Sieve opening in $\mu$ for equivalent Tyler mesh. 
During early operation with all new filters it was noted that some material passed through the porous media. After a few hours of operation this was no longer noticed. The material which did pass through was analyzed, and the size distribution is shown in Table 9.

TABLE 9. Particles Passing Through New 65-Micron Filter

$\begin{array}{rrrr}\begin{array}{r}\text { Screen Size, } \\ \mu \mathrm{m}\end{array} & & \text { Wt\% } \\ -210 & +210 & & 5.4 \\ -149 & +749 & & 1.7 \\ -74 & +37 & & 15.3 \\ -37 & +20 & & 41.4 \\ -20 & +10 & & 23.8 \\ -10 & +5 & & 10.1 \\ -5 & & & 0.2\end{array}$

Isokinetic sampling using a cascade impactor during typical runs was used to determine the particulate concentration and size in the off-gas passing through the filters. Results are shown in Table 10. The off-gas composition and typical filter operating conditions are shown in Table 11.

TABLE 10. Fluidized Bed Calciner Off-Gas Sampling (a)

$\frac{\text { Wt\% Lost }}{0.008-0.024} \frac{D F}{10^{3}-10^{5}} \frac{\begin{array}{c}\text { Mass } \\ \text { Concentration } \\ \mathrm{mg} / \mathrm{scf}(\mathrm{b})\end{array}}{0.004-0.35} \frac{\begin{array}{c}\text { Aerodynamic } \\ \text { Median Diameter, } \\ \text { Microns }\end{array}}{2.5-3.8}$

a. Average Conditions

$\begin{array}{lccc}\text { Pressure Drop, in. } \mathrm{H}_{2} \mathrm{O} & 20 & - & 40 \\ \text { Total acfm } & 80 & - & 90 \\ \text { Temperature, }{ }^{\circ} \mathrm{C} & 300 & - & 400 \\ \text { Face velocity, ft/min } & 3.97 & \pm & 0.66 \\ \text { Permeability, ft/min--in. } \mathrm{H}_{2} \mathrm{O} & 0.14 & \pm & 0.03 \\ \text { Pressure, in. } \mathrm{H}_{2} \mathrm{O} & -2 & \text { to } & -10\end{array}$

b. Noncondensable off-gas. 
TABLE 11. Fluidized Bed Calciner Off-Gas Composition (a,b)

\begin{tabular}{lcc} 
Component & & Mole \% \\
\cline { 1 - 1 } $\mathrm{CO}_{2}{ }^{(\mathrm{c})}$ & & 10.4 \\
$\mathrm{Ar}^{2}$ & 0.8 \\
$\mathrm{O}_{2}$ & 22.5 \\
$\mathrm{~N}_{2}$ & 65.5 \\
$\mathrm{CO}$ & $<0.1$ \\
$\mathrm{He}$ & $<0.01$ \\
$\mathrm{H}_{2}$ & 0.05 \\
$\mathrm{CH}_{4}$ & $<0.01$ \\
$\mathrm{~N}_{2} \mathrm{O}$ & 0.5 \\
$\mathrm{NO}_{\mathrm{X}}$ & 0.8
\end{tabular}

a. Average Conditions

$\begin{array}{lrrr}\text { Pressure Drop, in. } \mathrm{H}_{2} \mathrm{O} & 20 & - & 40 \\ \text { Total acfm } & 80 & - & 90 \\ \text { Temperature, }{ }^{\circ} \mathrm{C} & 300 & - & 400 \\ \text { Face velocity, ft/min } & 3.97 & \pm & 0.66 \\ \text { Permeability, ft/min--in. } \mathrm{H}_{2} \mathrm{O} & 0.14 & \pm & 0.03 \\ \text { Pressure, in. } \mathrm{H}_{2} \mathrm{O} & -2 & \text { to } & -10 \\ \text { Noncondensable off-gas. } & & & \\ \text { Unit heated by combustion of kerosene. } & & & \end{array}$

The permeability of the filters for the $\sim 300 \mathrm{hr}$ of accumulated operation is shown in Figure 7 . The filter permeability was lower initially than expected and is quite a bit lower than that of identical replacement filters. This has not been fully explained; however, some postulations have been made.

Schneider reported in earlier work done at Battelle that the spraying of raw water onto new filters frequently blinds them with a coating that cannot be blown off. (2) This was sometimes done during early shakedown runs. Also the off-gas impinged at high velocity on one filter as it entered the vessel. This filter was noted to respond less to blowback, hence indicating some plugging. To avoid blinding with water, the filters in the modified vesse 1 were precoated with $\mathrm{SiO}_{2}$ dust prior to introducing any liquids into the system. This was done by fluidizing and attriting a $\mathrm{SiO}_{2}$ bed without introducing feed. 


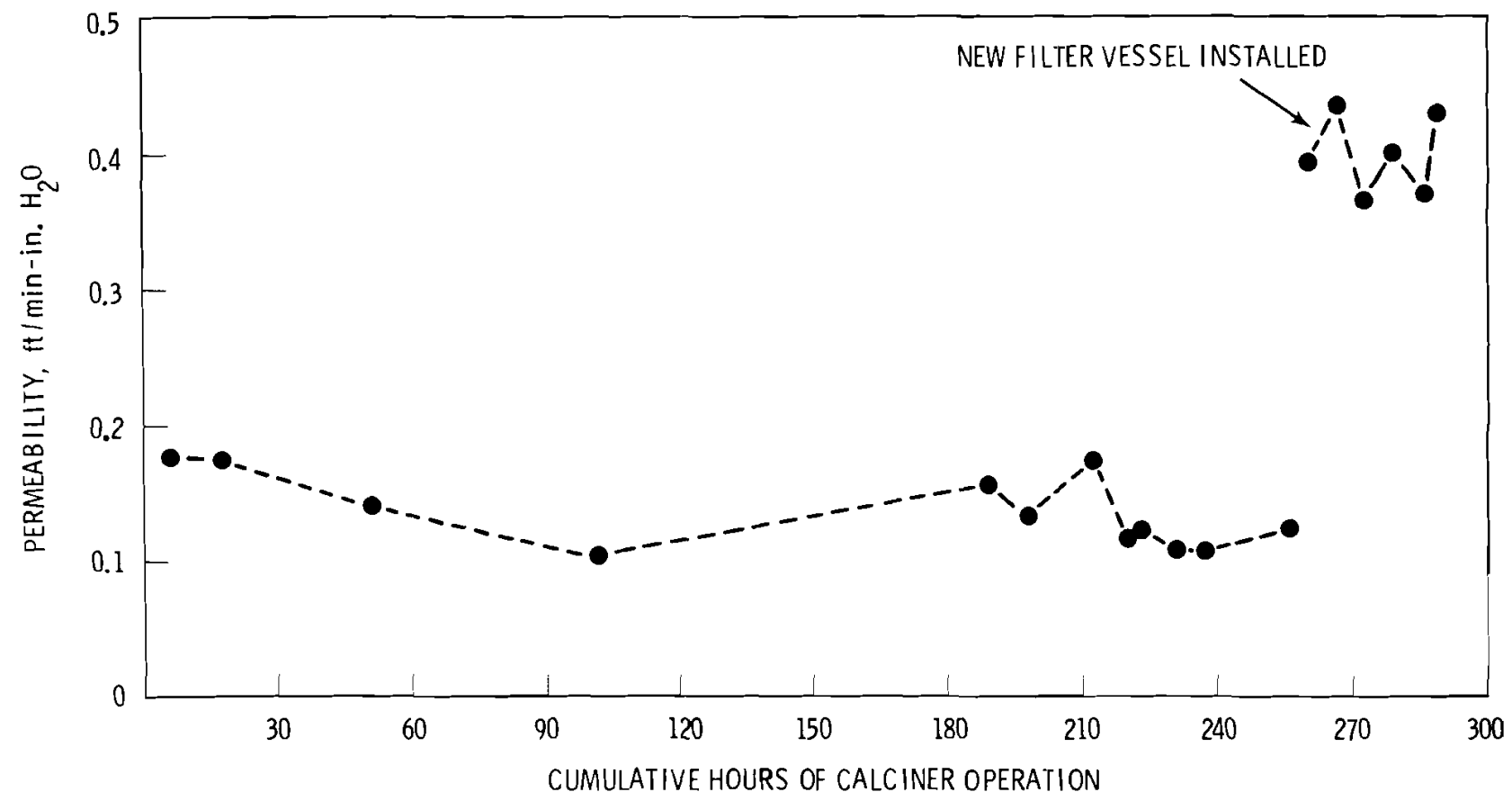

FIGURE 7. Permeability Data for Fluidized Bed Calciner

General operation with the initial set of filters was quite good. It soon became evident that the calciner capacity had increased significantly over its designed rate of $15 \mathrm{liter} / \mathrm{hr}$ with the new operating techniques. In operation at increased capacities, problems such as vacuum availability with existing plant off-gas equipment was a concern. Many runs were made with pressure drops of 30 to $40 \mathrm{in}$. of water, and frequent blowback ( 5 to 10 min cycle) was required. Although the filters performed satisfactorily, it was thought that lower differential pressure $(\triangle P)$ and much less blowback would be desirable and achievable. The useful life of the filters has been reported by many manufacturers to be lengthened by reducing blowback frequency.

A new filter chamber was designed and installed as described below.

\subsection{IMPROVED FILTER VESSEL}

The improved filter vessel installation was to accomplish several goals:

- increase filter area to obtain higher calciner feed rates

- run with lower pressure drop, $<10$ to $20 \mathrm{in}$. $\mathrm{H}_{2} \mathrm{O}$, and infrequent blowback 
- see if precoated filters would behave differently than those initially installed

- use different venturi designs and note any differences in blowback results

- use a cyclone prior to the filters.

The most efficient way of installing an enlarged filter section was to have the housing fabricated and then install it atop the housing from which the previous filters had been removed. See Figure 8. This left the original vessel serving no purpose except as a disengaging space. It was decided to modify the vessel to achieve a cyclone effect. This was done by installing a tangential gas inlet and modifying the gas outlet. It was evident that operating conditions would vary so much that the modified design would not result in optimum efficiency. Use of a cyclone with a spray calciner upstream of sintered metal filters had interfered with blowback efficiency. (7) This experience led to some concern; the assumption was that with the cyclone in place only the finest particles reached the filters and formed an especially adherent filter cake. However, it was felt that this would not happen with the fluidized bed since the particles are much larger. Cyclones have also been used as the major particulate removal system on fluidized beds such as at the waste calcination facility operated by Allied Chemical at the Idaho National Engineering Laboratory, Idaho Falls.

Eighteen sintered metal filters were used in the new vessel. Ten were $18 \times 2-3 / 4-i n$. diam, and seven were $36 \times 2-3 / 4-i n$. diam. They were arranged as shown in Figure 9. The blowback nozzles were piped so that two 18-in. filters would operate simultaneously and one 36-in. filter blown at a time. Frequency, cycle and duration of blowback were controlled from a specially designed timer panel. Several venturi designs such as are shown in Figure 3 were used. Blowback nozzles were the same as previously used.

Runs with the new filter vessel have far exceeded expectations. Although more hours are needed to verify operation, the following data has been accumulated:

- The precoat appeared effective in that the permeability of the filter is much higher than previous permeabilities (see Figure 7 ). 


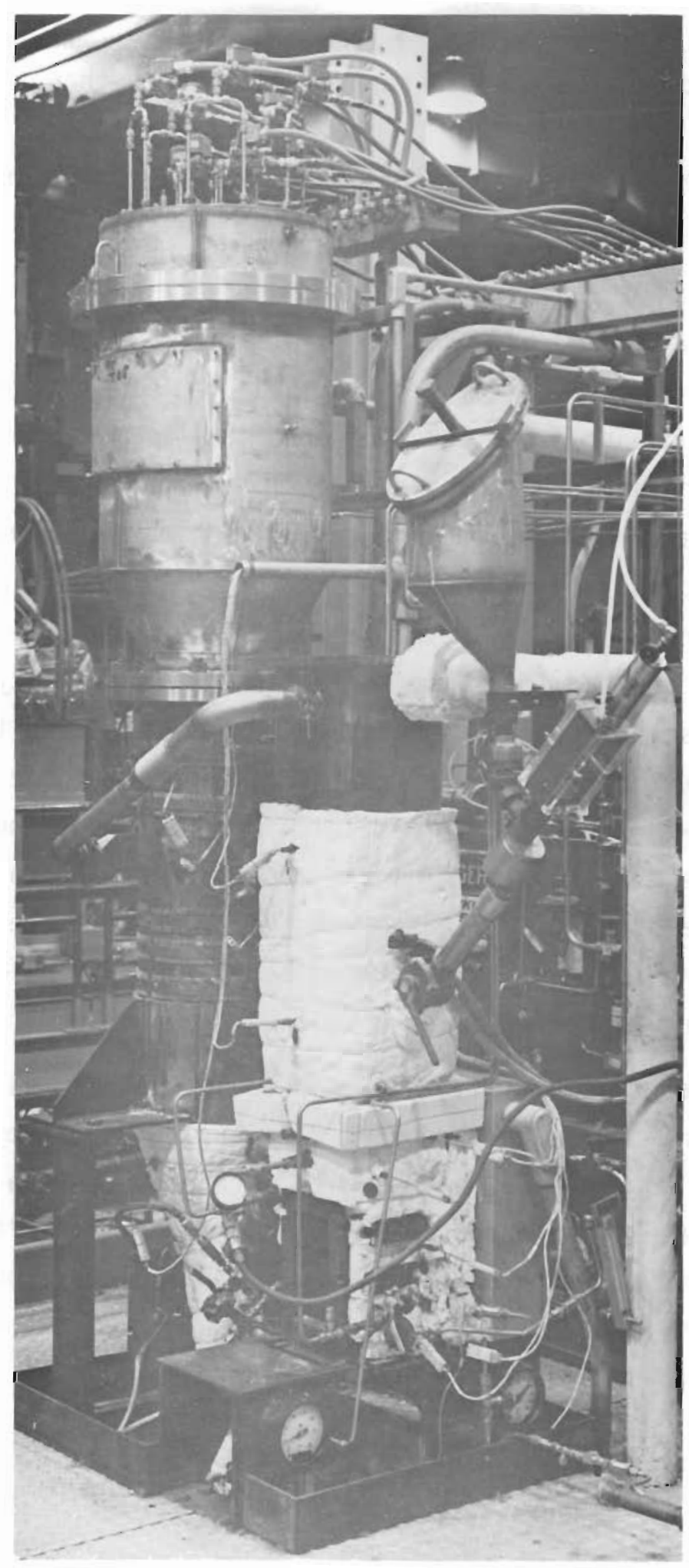

FIGURE 8. New Filter Vessel 


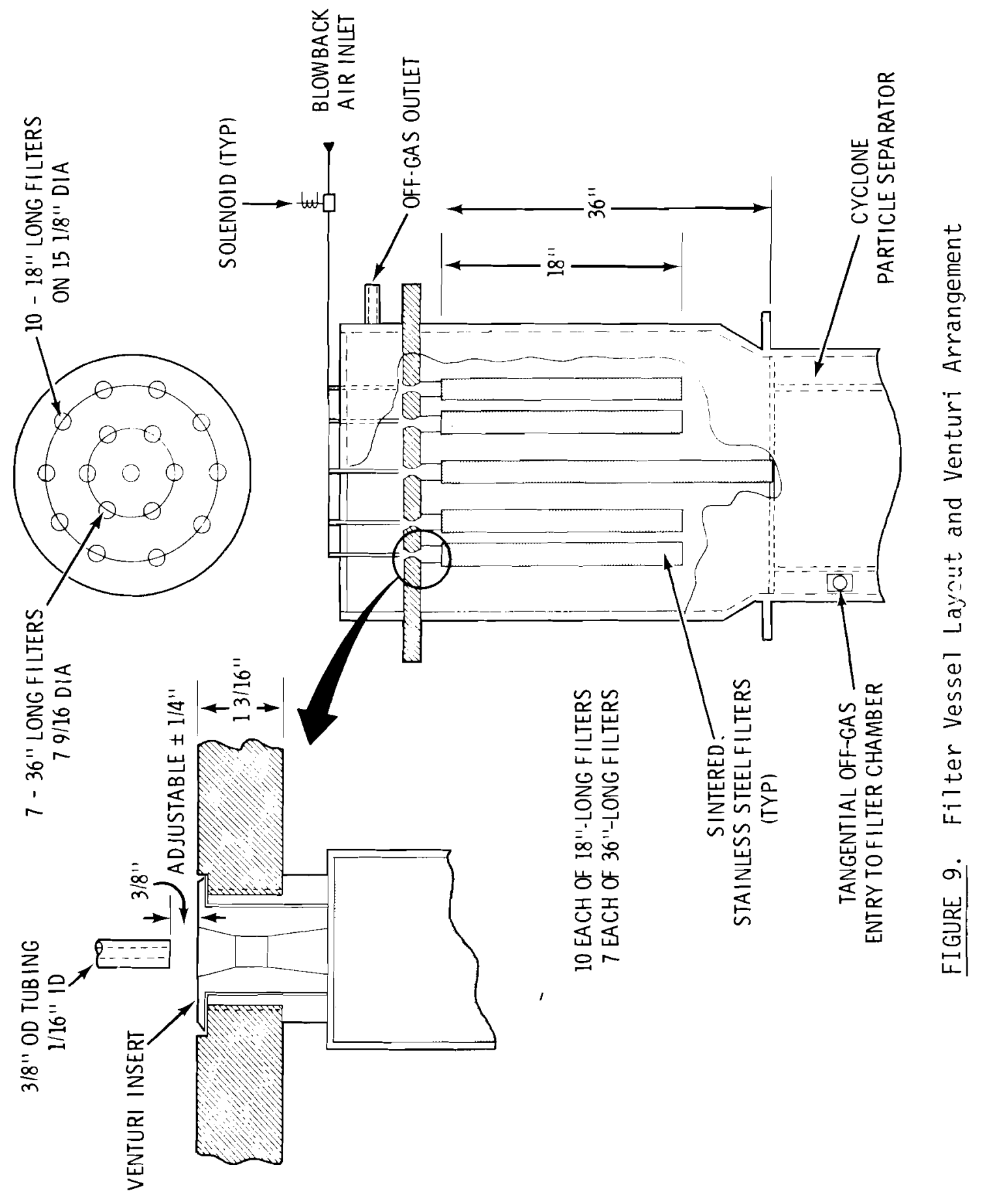


- Higher calciner feed rates were achieved.

- Pressure drop has been low, and it appears that very infrequent blowback will be required.

- The venturi dimensions tried have little if any noticeable effect on blowback.

- Quantified data on the cyclone efficiency have not been taken. However, observations of the solids loadings on the filters when no blowback is used indicate that the cyclone is removing most of the particles.

\subsection{SPRAY CALCINER}

Although feed solutions to the spray and fluidized bed calciners are identical, the nature of the particulates formed is not. Typical spray calcine properties are 1 isted in Table 12. Operating ranges the filters have been subjected to are shown in Table 13.

TABLE 12. Properties of Spray Calcine

$\begin{array}{lc}\text { Particle size, } u m & 3-20 \\ \text { Average bulk density, g/cc } & 1.1 \\ \text { Nitrate, wt\% } & 1-18 \\ \text { Moisture, wt\% } & 0.5 \\ \text { Angle of repose, degree } & 42\end{array}$

\section{TABLE 13. Operating Ranges}

$\begin{array}{lr}\text { Pressure drop, in. } \mathrm{H}_{2} \mathrm{O} & 10-20 \\ \text { Total acfm } & 30-90 \\ \text { Temperature, }{ }^{\circ} \mathrm{C} & 300-460 \\ \text { Face velocity, ft/min } & 1.6-5.6,(3.6 \pm 1.44 \mathrm{avg}) \\ \text { Permeability, ft/min-in. } \mathrm{H}_{2} \mathrm{O} \quad 0.28 \pm 0.05 \\ \text { Pressure, in. } \mathrm{H}_{2} \mathrm{O} \\ -10\end{array}$

Over $800 \mathrm{hr}$ of operation have been accumulated on the spray calciner. The spray calciner has 15 filters 24 in. long $\times 2$ in. diam. They are blown 
back in sets of three. Vessel design is as shown in Figure 10. The filters were designed to handle off-gas flows for calcining waste at $151 \mathrm{iter} / \mathrm{hr}$. The most intensive use of the filters was in a 500-hr continuous run. (11) Figure 11 shows the differential pressure $(\Delta P)$ during the run. The $\Delta P$ increased with increases in vapor velocity or solids loading but returned to a normal $10-i n$. $\mathrm{H}_{2} \mathrm{O}$ when design feed rates of $151 \mathrm{iter} / \mathrm{hr}$ were resumed.

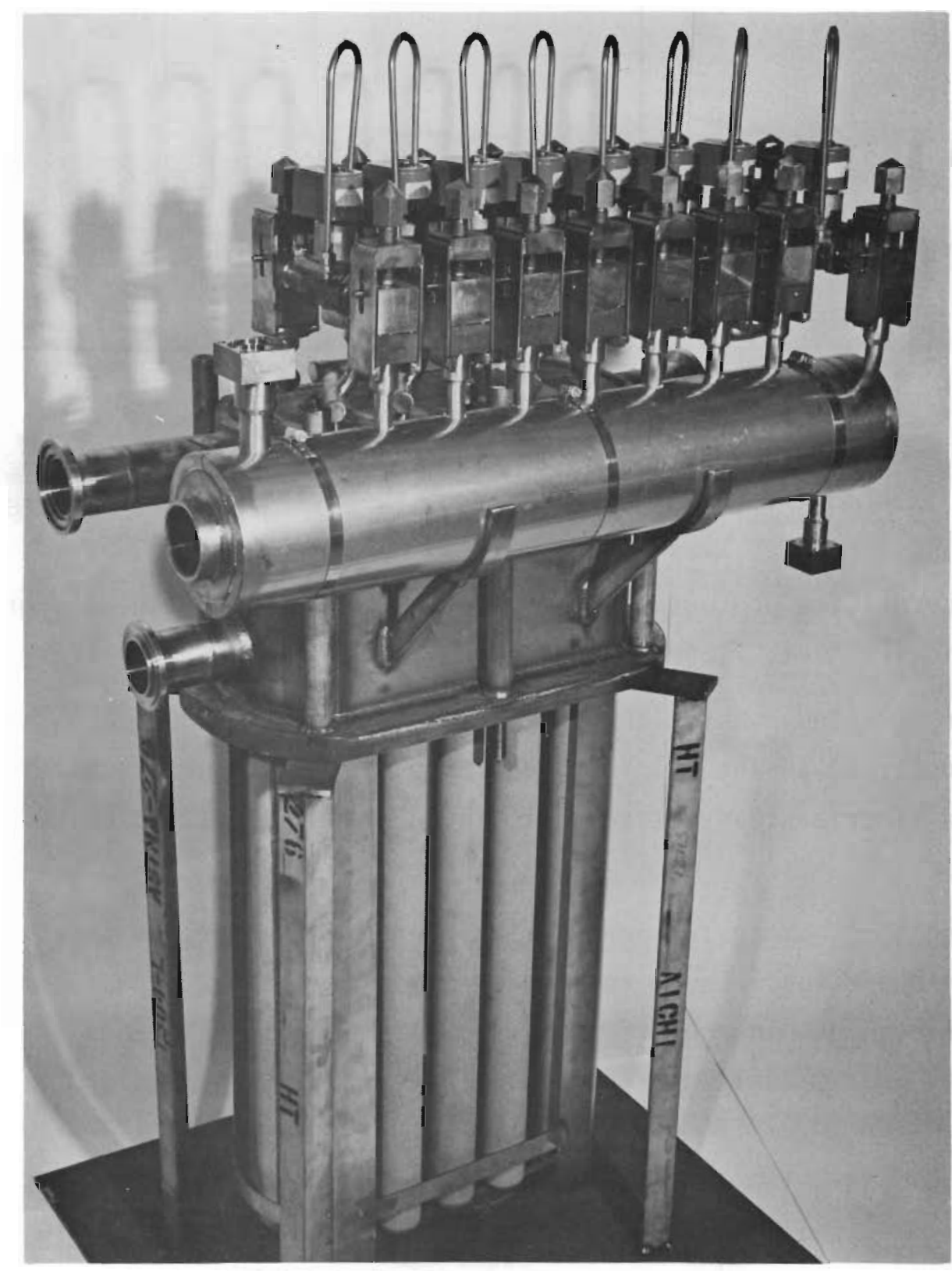

FIGURE 10. Spray Calciner Filters and Blowback Apparatus 


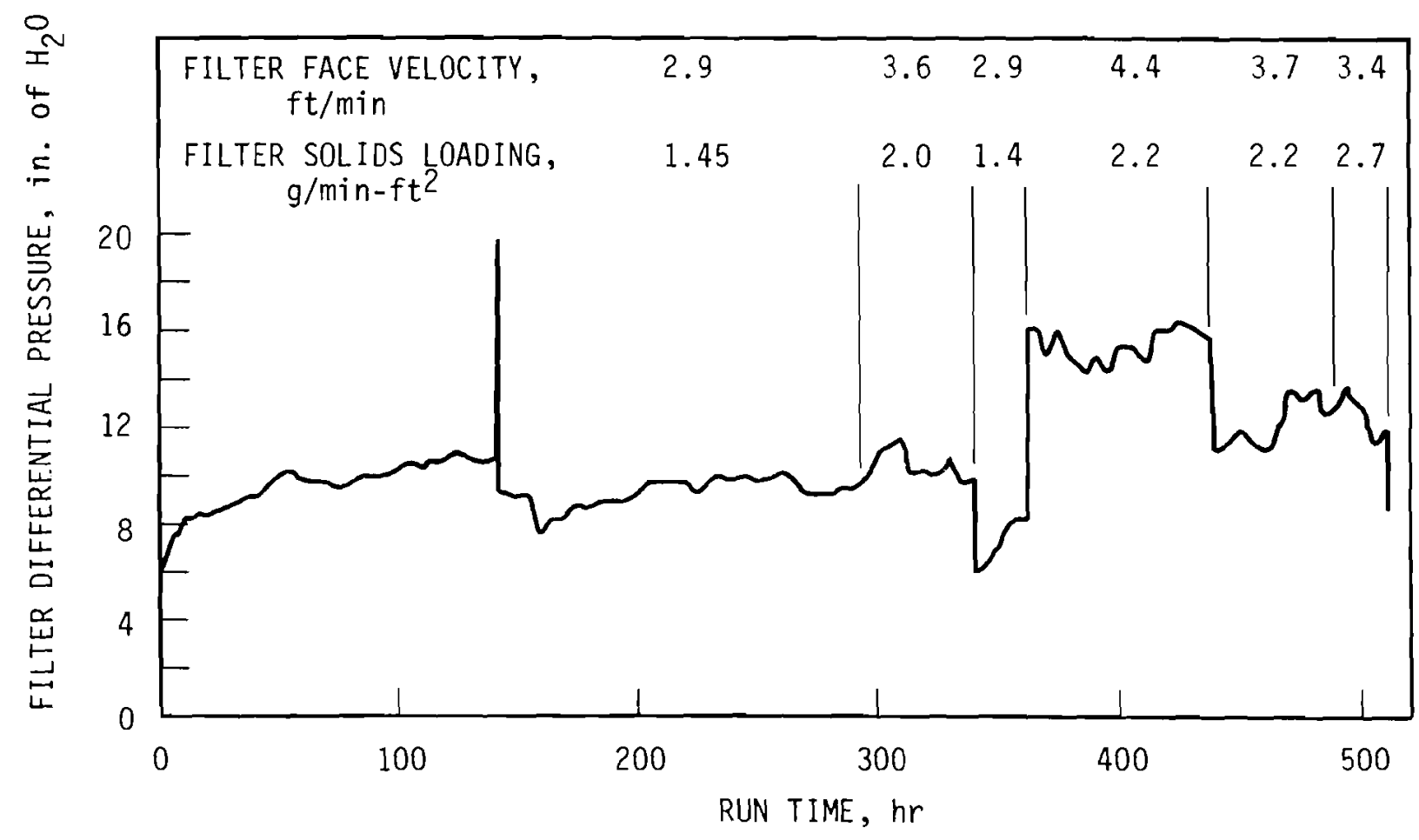

FIGURE 11. Spray Calciner Filter Differential Pressure

Figure 12, a photograph taken at the conclusion of the 500-hr run, shows the typical 1/16-in. layer of calcine which coats the filter.

Particulates passing through the off-gas filters were 0.05 to $0.5 \%$ of those contained in the calciner feed. As usual, higher decontamination was achieved after a steady-state, 1/16 in. coating of calcine accumulated on the filters.

Figure 13 summarizes permeability data from about $800 \mathrm{hr}$ of spray calcination operation. Early runs were at low feed rates because the unit was being broken in. The new figures gradually approach a steady-state permeability near $0.25 \mathrm{ft} / \mathrm{min}-\mathrm{in}$. $\mathrm{H}_{2} \mathrm{O}$. This value was maintained over the $500-h r$ run at $20.27 \mathrm{ft} / \mathrm{min}-\mathrm{in} . \mathrm{H}_{2} \mathrm{O}$.

In nearly all runs a typical cycle was maintained: blowback of 0.25 -sec pulses to three filters at a time every 2 min. This kept pressure drops near 10-in. $\mathrm{H}_{2} \mathrm{O}$. This frequent blowback cycle was inherited from operating previous calciner units. Those had limited off-gas vacuum available, necessitating 


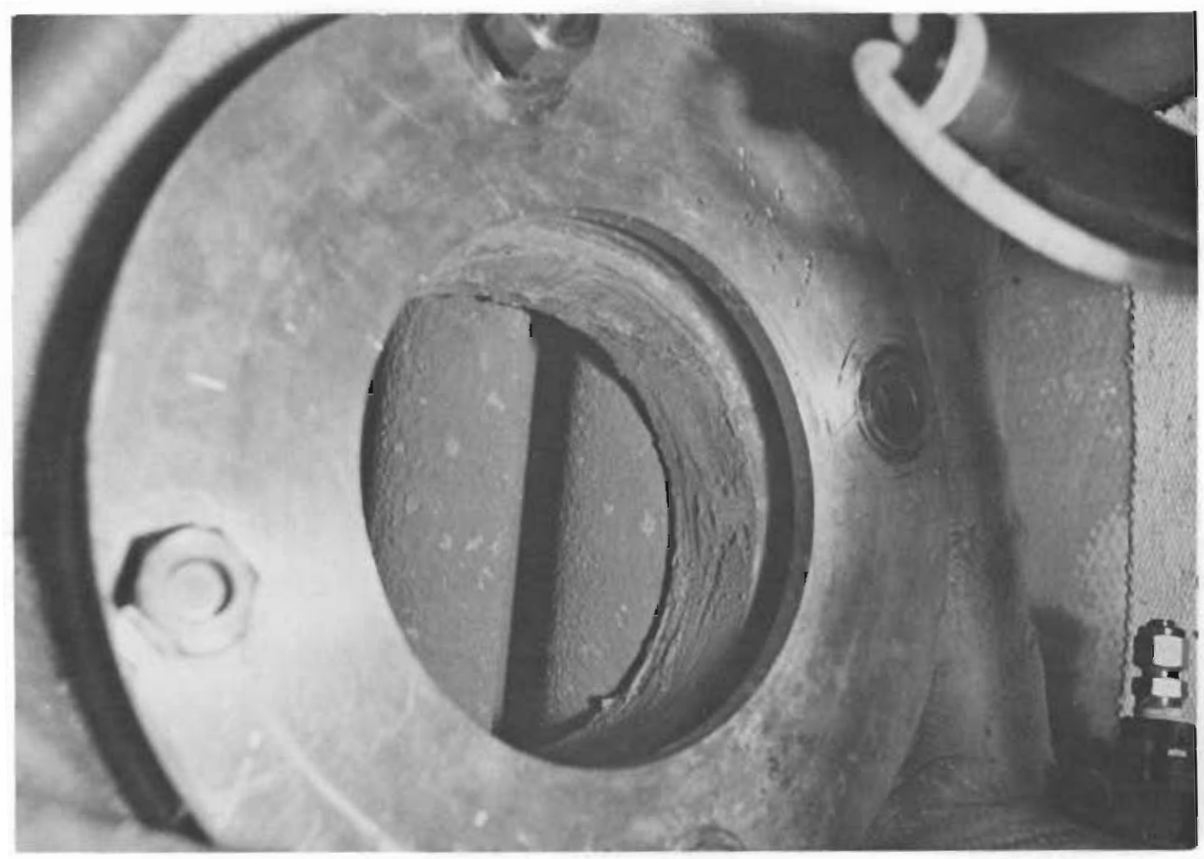

FIGURE 12. Off-Gas Filters Following 500-Hr Run

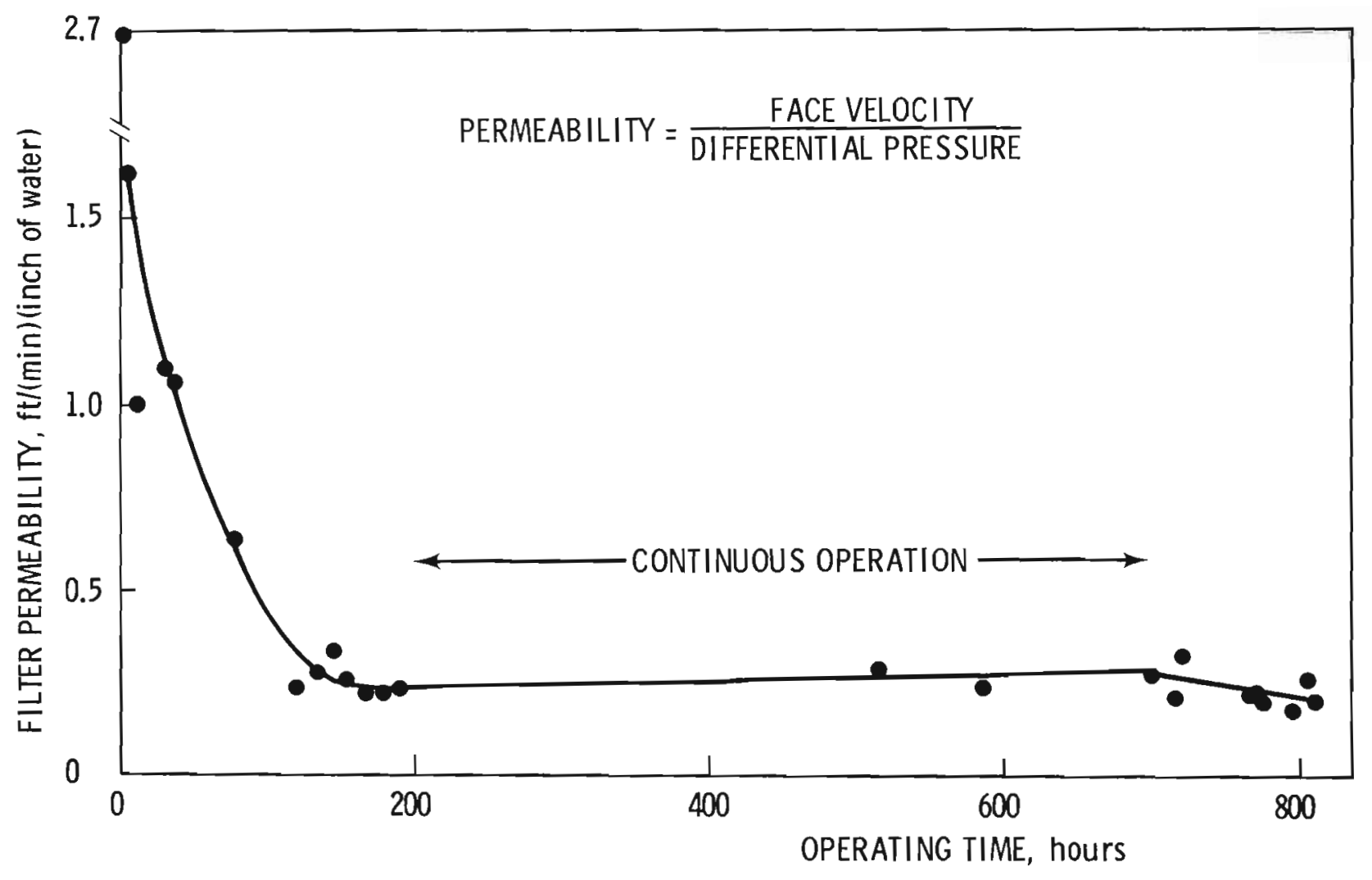

FIGURE 13. Spray Calciner Permeability Data 
frequent blowback to keep $\Delta \mathrm{P}$ low and to avoid vessel pressurization. More recent experience with the fluidized bed and spray calciner has shown this frequent blowback to be unnecessary and potentially harmful as long-term filter plugging may result. Blowback at hourly or greater intervals has been sufficient.

Pressure drop is allowed to build to higher values; then the filters are blown back to a low value. The cycle is spread then over a wider range for a longer duration. Of course, this requires sufficient off-gas handling facilities. A steam jet to boost low vacuum systems has proven quite useful.

Remote Solenoid Valve Placement

Full size calcination equipment for commercial operation would require up to a hundred or more sintered metal filters. The blowback piping, solenoids, etc., become cumbersome for remote maintenance. To avoid having this equipment in the cel1, tests were tried with the spray calciner filter vessel. The solenoid valves were located $15 \mathrm{ft}$ from the venturi tubes; normally the solenoid is as close as practical to the vessel. Although the impulse for short pulses is weaker with the solenoids placed remotely, it appears sufficient for effective blowback. Further tests are planned. 


\subsection{CONCLUSIONS AND RECOMMENDATIONS}

1. Sintered metal filters are a very effective means of particulate off-gas cleanup in either a spray calciner or fluidized bed.

2. Properly designed systems can operate with low pressure drop and require very infrequent blowback.

3. Blowback is an effective way of periodically cleaning sintered metal filters.

4. Use of a combustion heating system had no apparent effect on filter performance.

5. Sophisticated blowback design is not required for most operating conditions. High-pressure air through typical venturi nozzles is almost always sufficient.

6. Filters should be precoated prior to introducing vapors to the system, and the filters should never be operated below the vapor dew point. Filter temperatures for tests described in this report were $\sim 300$ to $500^{\circ} \mathrm{C}$.

7. Inclusion of more filtering area than calculated is encouraged; i.e., low face velocity $<3 \mathrm{ft} / \mathrm{min}$ is recommended.

8. Avoid repetitive blowback; use as infrequent a blowback cycle as convenient. Allowing a cake to build on the filters improves their efficiency.

9. Smal1 pore size filters are recommended by manufactures; however, no problems were encountered using 65- $\mu$ material.

10. Reinforcing grids are encouraged for filters if structural integrity is important.

11. Feed additives such as cabosil, used to aid filter performance, were tried on a limited basis. Results were inconclusive.

12. The most serious problems in using sintered metal filters would be breaching the filter media or caking and plugging the filter media with a substance which could not be blown off. 
13. Filtration of off-gas from the melters in which calcine and glass additives are melted showed no $i 11$ effects over the short-term runs.

14. Further testing to specifically trace volatile species such as ruthenium and cesium is recommended. 


\subsection{REFERENCES}

1. E. L. Carls and N. M. Levitz, Blowback of Sintered-Metal Filters: A Review of Tests and Operating Experience, ANL-7392, Argonne National Laboratory, Argonne, IL, January 1968.

2. K. J. Schneider and V. P. Kelley, Waste Solidification Program, vol. 2, Design Features of the Waste Solidification Engineering Prototype, BNWL-968, pp. $6.12-6.14$, Battel7e-Northwest, Richland, WA, February 1969.

3. W. R. Bond et al., Waste Solidification Program, vol. 8, Spray Solidification Performance During Final Radioactive Tests in Waste Solidification Engineering Prototype, BNWL-1583, pp. 3.36-3.39, 4.27-4.29, Battelle-Northwest, Richland, WA, June 1971.

4. K. J. Schneider, Recent Waste Solidification Engineering Development in the Chemical Development Operation, Battelle-Northwest, Richland, WA, March 1964.

5. M. E. Spaeth, "Spray Calciner Filter Cleaning," Quarterly Progress Report, Research and Development Activities, Fixation of Radioactive Residues, January - March 1965, BNWL-76, Battel7e-Northwest, Richland, WA, Apri1 1965.

6. D. B. Pall, "Filtration of Fluid Catalyst Fines from Effluent Gases," Industrial and Engineering Chemistry, p. 1198, June 1953.

7. J. D. Kaser and J. D. Moore, "The Development of a Spray Calciner Melter," BNWL-SA-515, Battelle-Northwest, Richland, WA, February 1966.

8. J. D. Kaser, "Filter Blowback Studies," Quarterly Progress Report, Research and Development Programs Executed for the Division of Reactor Development, October, November, December 1963, HW-80284, Richland, WA, Apri1 1964.

9. R. Dennis et al., Laboratory Performance of the Mikro-Pulsaire Collector, NY0-4816, pp. $34-35$, Harvard University Air Cleaning Laboratory, Boston, MA, June 1962.

10. Waste Fixation Monthly Progress Report, Battelle-Northwest, Richland, WA, WFP-1276, December 1973.

11. J. L. McElroy, compiler, Quarterly Progress Report, Research and Development Activities, Waste Fixation Program, BNWL-1847, Battelle, Pacific Northwest Laboratories, Richland, WA, July 1974. 
BNWL-2074

UC -70

\section{DISTRIBUTION}

No. of

Copies

OFFS ITE
No. of

Copies

OFFSITE
A. A. Churm

ERDA Chicago Patent Group

9800 South Cass Avenue

Argonne, IL 60439

S. H. Smiley

Deputy Director for Fuels

and Materials

NRC Directorate of. Licensing

for Fuels and Materials

4915 St. Elmo Avenue

Bethesda, MD 20014

R. B. Chitwood

Chief, Technical Support Branch

for Fuels and Materials

NRC Directorate of Licensing

for Fuels and Materials

4915 St. Elmo Avenue

Bethesda, MD 20014

W. P. Bishop

Chief, Waste Management Branch

NRC Division of Materials and

Fuel Cycle Facility Licensing

Washington, DC 20555

J. Parry

NRC Division of Materials and

Fuel Cycle Facility Licensing

Washington, DC 20555

W. G. Belter

ERDA Division of Biomedical and

Environmental Research

Earth Sciences Branch

Washington, DC 20545

W. E. Mott

ERDA Division of Environmental

Control Technology

Washington, DC 20545
F. P. Baranowsk $j$

ERDA Division of Nuclear Fuel

Cycle and Production

Washington, DC 20545

G. H. Daly

ERDA Division of Nuclear Fuel

Cycle and Production

Washington, DC 20545

C. R. Cooley

ERDA Division of Nuclear Fuel

Cycle and Production

Washington, DC 20545

0. P. Gormley

ERDA Division of Nuclear Fuel

Cycle and Production

Washington, DC 20545

C. Kuhlman

ERDA Division of Nuclear Fuel

Cycle and Production

Washington, DC 20545

A. F. Perge

ERDA Division of Nuclear Fuel

Cycle and Production

Washington, DC 20545

R. W. Ramsey

ERDA Division of Nuclear Fuel

Cycle and Production

Washington, DC 20545

R. D. Walton

ERDA Division of Nuclear Fuel

Cycle and Production

Washington, DC 20545 
No. of

Copies

K. K. Kennedy

ERDA Idaho Operations Office

P. 0. Box 2108

Idaho Falls, ID 83401

E. H. Hardison

ERDA Oak Ridge Operations

Office

P. 0. Box $X$

Oak Ridge, TN 37830

R. L. Chandler

ERDA Savannah River Operations Office

P. 0. Box A

Aiken, SC 29801

27 ERDA Technical Information Center

J. A. Buckham

Allied Chemical Corporation

550 - 2nd Street

Idaho Falls, ID 83401

B. R. Dickey

Allied Chemical Corporation 550 - 2nd Street

Idaho Fa11s, ID 83401

W. J. Price

Allied-General Nuclear

Services

P. 0. Box 847

Barnwe11, SC 29812

W. J. Godfrey

Allied-General Nuclear

Services

P. 0. Box 847

Barnwe11, SC 29812

A. K. Williams

Allied-General Nuclear

Services

P. 0. Box 847

Bariwe 11, SC 29812
No. of

Copies

M. J. Steindler

Argonne National Laboratory

9700 South Cass Avenue

Argonne, IL 60439

Bechtel Corporation

50 Bəale Street

San Francisco, CA 9:1119

M. Steinberg

Brookhaven National Laboratory

Research Library, Reference

Section

Information Division

Upton, Long Is land, NY 11973

Alfred W. Allen

C-E Refractories

Box 828

Valley Forge, PA 19482

R. Beekmann

Combustion Engineering, Inc.

Combustion Division

Windsor, CT 06095

3 M. G. Britton

Corning Glass Works

Technical Staffs Division

Corning, NY 14830

D. L. Ziegler

Dow Chemical Company (ERDA)

Rocky Flats Division

P. 0. Box 888

Golden, C0 80401

R. F. Bradley

E. I. du Pont de Nemours and Co.

Savannah River Laboratory

Aiken, SC 29801

C. H. I ce

E. I. du Pont de Nemours and Co.

Savannah River Laboratory

Aiken, SC 29801 
A. S. Jennings

E. I. du Pont de Nemours and Co.

Savannah River Laboratory Aiken, SC 29801

J. A. Kelley

E. I. du Pont de Nemours and Co.

Savannah River Laboratory Aiken, SC 29801

R. F. Williams

Electric Power Research

Institute

$3412 \mathrm{Hi} 11$ view Avenue

P. 0. Box 10412

Palo Alto, CA 94304

G. L. Meyer

Environmental Protection Agency

Technology Assessment Division (AW-559)

Office of Radiation Programs

Washington, DC 20460

S. J. Beard

Exxon

Richland, WA 99352

L. T. Lakey

Exxon

Richland, WA 99352

M. E. Spaeth

Exxon

Richland, WA 99352

R. G. Barnes

General Electric Company

175 Curtner Avenue

(M/C 160)

San Jose, CA 95125

A. Carson

General Electric Company

175 Curtner Avenue

(M/C 160)

San Jose, CA 95125
L. H. Brooks

General Atomic Company

P. 0. Box 81608

San Diego, CA 92138

J. J. Shefcik

General Atomic Company

P. 0. Box 81608

San Diego, CA 92138

G. Cowen

Los Alamos Scientific Laboratory (ERDA)

P. 0. Box 1663

Los Alamos, NM 87544

J. P. Duckworth, Plant Manager

Nuclear Fuel Services, Inc.

P. 0. Box 124

West Valley, NY 14171

W. Lewis, Vice President

Nuclear Fuel Services, Inc.

6000 Executive Blvd., Suite 600

Rockville, MD 20852

4 Oak Ridge National Laboratory

(ERDA)

Central Research Library, Document Reference Section

Central Research Library, ORNL

Laboratory Records Dept., ORNL

Laboratory Records Dept., ORNL-RC

P. 0. Box X

Oak Ridge, TN 37830

G. J. McCarthy

Pennsylvania State University

Materials Research Laboratory

University Park, PA 16802

R. W. Lynch

Sandia Laboratories

Albuquerque, NM 87107

W. Weart

Sandia Laboratories

Albuquerque, NM 87107 
No. of

Copies

P. D. O'Brien

Sandia Laboratories

A1buquerque, NM 87107

J. 0. Blomeke

Union Carbide Corporation

(ORNL)

Chemical Technology Division

P. 0. Box $Y$

Oak Ridge, TN 37830

H. W. Godbee

Union Carbide Corporation

(ORNL)

Chemical Technology Division

P. 0. Box Y

Oak Ridge, TN 37830

C. D. Zerby

Union Carbide Corporation (ORNL)

Chemical Technology Division

P. 0. Box $Y$

Oak Ridge, TN 37830

\section{ONSITE}

ERDA Richland Operations office

Programs Division

3 ERDA Richland Operations office

Production and Waste Management

Program Division

0. J. Elgert

R. B. Goranson

C. R. Palmer

ERDA Richland Operations office Safety and Quality Assurance Div.

J. H. Straub, Director

4 Atlantic Richfield Hanford Co.

R. E. Isaacson

D. C. Nelson

W. W. Shulz

File Copy
No. of

Copies

United Nuclear Industries, Inc.

2 Westinghouse Hanford Company

R. E. Lerch

G. L. Richardson

45 Battelle-Northwest

T. W. Ambrose

J. W. Bartlett

W. J. Bjorklund (10)

H. T. Blair

W. F. Bonner

D. J. Bradley

J. R. Carre11

N. E. Carter

C. C. Chapman

T. D. Chikalla

R. D. Dierks

J. W. Finnigan

A. A. Garrett

T. A. Golding

M. S. Hanson

Y. B. Katayama

W. S. Kelly

R. S. Kemper

R. P. Marsha 11

J. L. MCEl roy

J. E. Mendel

R. E. Nightingale

D. E. Olesen

A. M. Platt

F. P. Roberts

W. A. Ross

J. M. Rusin

D. H. Siemens

R. P. Turcotte

J. H. Westsik, Jr.

L. D. Williams

W. K. Winegardner

Technical Information (3)

Technical Publications 